\title{
Cognitive performance and mood in patients on the waiting list for liver transplantation and their relation to the model for end-stage liver disease
}

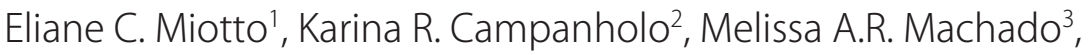 \\ Glaucia G.R. Benute ${ }^{4}$, Mara C.S. Lucia ${ }^{5}$, Renério Fráguas Jr ${ }^{6}$, \\ Telesforo Bacchella ${ }^{7}$, Marcel C.C. Machado ${ }^{8}$
}

\begin{abstract}
Objective: To investigate the links between depression and cognitive functioning in patients with Hepatitis $C$ and other chronic liver diseases with and without the use of alcohol on the waiting list for liver transplantation and their associations with the MELD classification. Method: 40 patients were evaluated on a waiting list for liver transplant by a battery of neuropsychological tests, depression scales and interview at the Liver Transplant Service, of the Hospital das Clínicas University of São Paulo Medical School. Results: After splitting the sample according to the education, the results showed statistical significance in the comparisons between groups of MELD $\geq 15$ and $<15$ in the following functions: estimated IQ, visual-spatial delayed recall and recognition as part of episodic memory and short term memory. Conclusion: These findings, usually found in hepatic encephalopathy, corroborated with the literature and emphasized the need to investigate in more detail the cognitive functions of these patients in order to facilitate the adoption of different conducts. Key words: hepatic encephalopathy, cognitive deficits, neuropsychology, MELD.
\end{abstract}

Desempenho cognitivo e humor em pacientes em lista de espera de transplante de fígado e suas relações com modelo para doença hepática e fase terminal

\section{RESUMO}

Objetivo: Investigar as relações entre depressão e funcionamento cognitivo em pacientes portadores de hepatite $\mathrm{C}$ e demais doenças hepáticas crônicas com e sem uso de álcool em fila de espera para transplante hepático e suas relações com a classificação MELD. Método: Foram avaliados 40 pacientes em lista de espera para transplante hepático por bateria de testes neuropsicológicos, escalas de depressão e entrevista no Serviço de Transplante do Fígado do HC-FMUSP. Resultados: Após divisão da amostra por escolaridade os resultados mostraram significância estatística nas comparações entre grupos de MELD $\geq 15$ e <15 nas funções: Ql estimado, memória episódica de evocação tardia e de reconhecimento visuo-espacial e memória de curto prazo. Conclusão: As dificuldades encontradas, comuns

\section{Correspondence}

Eliane C. Miotto

Divisão de Psicologia

Hospital das Clinicas FMUSP

Av. Dr Enéas de Carvalho Aguiar 155

PAMB / Terro.

05403-000 São Paulo SP - Brasil

E-mail: ecmiotto@usp.br

Received 16 June 2009

Received in final form 15 September 2009 Accepted 21 September 2009 ao quadro de encefalopatia hepática, corroboram a literatura pesquisada e enfatizam a necessidade de se investigar de maneira mais detalhada o funcionamento cognitivo destes pacientes, uma vez que diferentes condutas podem ser adotadas.

Palavras-chave: encefalopatia hepática, déficits cognitivos, neuropsicologia, MELD.

Division of Psychology and Liver Transplant Service of the Hospital das Clínicas, University of São Paulo Medical School (DP/HCFMUSP), São Paulo SP, Brazil: 'Clinical Director of the Division of Psychology, and PhD in Neuropsychology; ${ }^{2}$ Neuropsychologist and Research Trainee, Division of Psychology, HC-FMUSP; ${ }^{3}$ Neuropsychologist, Division of Psychology, HC-FMUSP; ${ }^{4}$ Research Director, Division of Psychology, HC-FMUSP; ${ }^{5}$ Director, Division of Psychology, HC-FMUSP; ${ }^{6}$ Psychiatrist, Department of Psychiatry, HC-FMUSP; ${ }^{7}$ Director, Liver Transplant Service, HC-FMUSP; ${ }^{8}$ Professor, Liver Transplant Service, HC-FMUSP. 
Hepatic cirrhosis is often associated with neuropsychiatric disorders including disorders of personality, affection, sleep, inappropriate behavior and cognitive deficits $^{1-3 .}$ The combination of these symptoms is known as hepatic encephalopathy (HE) and causes great impact on daily life activities. Neuropsychological studies in cirrhotic patients in the early stages of HE have shown cognitive dysfunction related to intellectual abilities, psychomotor functions, visual-perceptual, visual-spatial and visualconstructional skills, attention ${ }^{4}$ and memory functions ${ }^{5}$. Based on these findings, various neuropsychological batteries have been used in the study of these patients as, for example, the PSE-Test ${ }^{4,5}$. This battery is composed of tests of attention and of short term memory and has been used to indicate the presence of a condition known as pre-clinical minimal HE (MHE) $)^{3-5}$. Another important problem associated with diseases of the liver is the presence of mood disorders, with depression as the main symptom in cirrhotic patients ${ }^{6,7}$. In patients with cirrhosis related to hepatitis $\mathrm{C}$ the mood disorders may be part of the neuropsychological syndrome associated with the infection ${ }^{2}$. According to some studies, $56.7 \%$ of these patients had minimal depression, $40.7 \%$ mild to moderate depression, $10 \%$ moderate to severe depression and 6\% extremely severely depression ${ }^{1}$. A number of studies have shown that the severity of the liver diseases is an important predictor of the severity of psychiatric disorders. The Child-Pugh classification ${ }^{8}$ is one reliable predictor for the occurrence of depression and other symptoms such as, sleep and sexual disorders, fatigue and history of psychiatric diseases ${ }^{1,9}$. This instrument provides a prognostic classification made from two clinical data: ascites and hepatic encephalopathy, and three laboratory findings: levels of total bilirubin, albumin and activity of prothrombin. When these scores are added up they provide three levels of classification namely $\mathrm{A}, \mathrm{B}$ and $\mathrm{C}$, with the last being the most severe ${ }^{10}$.

Currently, there is a more objective measure for the severity of this condition known as MELD ${ }^{11}$ (Model for End-stage Liver Disease). This measure summarizes three laboratory parameters that are obtained in any routine exam of chronic liver disease, namely the bilirubin, the creatinine and INR (International Normalized Ratio) which deals with measuring the activity of prothrombin. The results of these tests are transferred to a mathematical formula, which is the numerical result of the MELD ${ }^{11}$. In Brazil, in 2006, this measure of severity of liver disease was established as a criterion for admission and priority on the waiting list for liver transplant in individuals over 12 years. The first patients in the list are the most serious ones in a position to receive transplants (Regulation 1.160 of May $\left.29^{\text {th }}, 2006\right)^{12}$.

The purpose of this study was to investigate the cognitive functioning and mood in patients with cirrhosis relat- ed to hepatitis $C$ and other chronic hepatic diseases with and without alcohol abuse on the waiting list for liver transplantation and its relationship to MELD classification.

\section{METHOD}

In this prospective and transversal study, 47 patients included in the waiting list for liver transplantation based on the severity of hepatic illness MELD, with hepatitis C and other liver diseases with and without the use of alcohol were included. They received treatment and follow up intervention in the Transplant Service out patient clinic of Hospital das Clínicas, University of São Paulo School of Medicine (HC-FMUSP) and were on the waiting list for hepatic transplantation.

Patients with encephalopathy level II and illiterates were excluded. All the patients underwent a neuropsychological assessment and signed the Informed Consent approved by the Ethical Committee of the HC-FMUSP. Seven patients were excluded due to the impossibility to complete the assessment, four for invalidation of some tests. A total of 40 patients were considered in the final analyzes.

The participants were submitted to a protocol composed of semi-structured interview for the socio-demographic and clinical data collection, history of alcoholism based on the cutdown, annoyed, guilty, eyeopener (CAGE) and alcohol use disorders identification test (AUDIT). For the research of depressive disorders it was administered the Beck Depression Inventory - BDI ${ }^{13}$. For those patients who presented scores greater than 20 which indicate moderate depression, it was administered the interview SCID ${ }^{14}$. In addition, a battery of neuropsychological tests were used and their order of application can be seen on Table 1.

The results were analyzed using the SPSS v. 10 (SPSS Inc.), adopting the significance level of $0.05(\alpha=5 \%)$. Nonparametric tests were used including the Wilcoxon, Mann Whitney and Kruskal-Wallis.

\section{RESULTS}

From the 40 patients who remained in the study, 67.5\% were male and $32.5 \%$ women. History of alcohol abuse in the past for the sample was $45 \%$. In terms of the diagnoses, $42.5 \%$ of the subjects had hepatitis $C$ and amongst those $15 \%$ had history of alcohol abuse. The remaining $57.5 \%$ of the patients had other hepatic diseases with 30\% of this sample with history of alcohol abuse. According to the scores obtained on the MELD the patients were divided into two groups (MELD $\geq 15$ and MELD $<15$ ) with scores above 15 indicating greater severity of hepatopaty $^{12}$. In this study, $52.5 \%$ of the patients had MELD $\geq 15$ and $47.5 \%$ had MELD $<15$.

Firstly, the two groups were compared in terms of the neuropsychological tests and depression scales and the 
Table 1. Neuropsychological functions and tests.

\begin{tabular}{|c|c|}
\hline Neuropsychological functions & Tests \\
\hline Intellectual functions & $\begin{array}{l}\text { Subtests Vocabulary and Matrix } \\
\text { Reasoning (WAIS-III) })^{15,16} \text {. }\end{array}$ \\
\hline $\begin{array}{l}\text { Memory functions } \\
\text { Short term memory } \\
\text { Verbal episodic memory of evocation immediate, late and of recognition } \\
\text { Visual-spatial episodic memory of evocation immediate, late and of recognition }\end{array}$ & $\begin{array}{l}\text { Subtest Digits (WAIS-III) })^{15} \\
\text { Hopkins Verbal Learning Test }-\mathrm{R}(\mathrm{HVLT}-\mathrm{R})^{17} \\
\text { Brief Visual Memory Test - R (BVMT-R) }\end{array}$ \\
\hline $\begin{array}{l}\text { Attention } \\
\text { Sustention attention } \\
\text { Alternate attention } \\
\text { Selective attention }\end{array}$ & $\begin{array}{l}\text { Trail Making Test A e B }(\mathrm{TMT})^{19} \\
\text { Stroop Test }{ }^{19}\end{array}$ \\
\hline $\begin{array}{l}\text { Executives functions } \\
\text { Nominal Fluency } \\
\text { Category Fluency }\end{array}$ & $\begin{array}{l}\text { FAS-Test }{ }^{19} \\
\text { Category Fluency - animals }{ }^{19}\end{array}$ \\
\hline Speed information proceeding & Symbol Digit Modality Test - Oral version ${ }^{20}$ \\
\hline Visual-construction & Clock draw ${ }^{21}$ \\
\hline Psychomotor speed & Grooved Pegboard Test ${ }^{21}$ \\
\hline
\end{tabular}

Table 2. Comparison of averages and significance statistics in groups of MELD and years of schooling to 40 patients of the hepatic transplant list of the HC-FMUSP.

\begin{tabular}{|c|c|c|c|c|c|c|}
\hline & \multicolumn{3}{|c|}{ MELD } & \multicolumn{3}{|c|}{ Years of education } \\
\hline & $\begin{array}{c}\geq 15 \\
\mathrm{n}=21 \text { mean }(\mathrm{SD})\end{array}$ & $\begin{array}{c}<15 \\
\mathrm{n}=19 \text { mean }(S D)\end{array}$ & $\begin{array}{l}\text { Value } \\
\text { of } p\end{array}$ & $\begin{array}{c}\text { Group } 1 \\
\text { (education }>8 \text { ) } \\
\mathrm{n}=19 \text { mean }(\mathrm{SD})\end{array}$ & $\begin{array}{c}\text { Group } 2 \\
\text { (education } \leq 8 \text { ) } \\
\mathrm{n}=21 \text { mean }(\mathrm{SD})\end{array}$ & $\begin{array}{l}\text { Value } \\
\text { of } p\end{array}$ \\
\hline Schooling (years) & $7.67(4.16)$ & $8.37(3.52)$ & .670 & $11.42(2.04)$ & $4.9(1.95)$ & 0.01 \\
\hline MELD & $19.24(2.83)$ & $11.74(1.73)$ & $.000^{* *}$ & $14.63(4.42)$ & $16.62(4.38)$ & 0.14 \\
\hline BECK & $11.52(6.68)$ & $11.89(7.52)$ & .817 & $10.84(6.8)$ & $12.48(7.26)$ & 0.6 \\
\hline SCID & $0.57(1.8)$ & $0.63(1.89)$ & .917 & $0.32(1.38)$ & $0.86(2.15)$ & 0.35 \\
\hline Vocabulary & $34.05(10.15)$ & $31.95(8.95)$ & .569 & $37.42(9.01)$ & $29.1(8.34)$ & $0.01^{* *}$ \\
\hline Matrix reasoning & $11.38(5.58)$ & $14.11(3.49)$ & $.073^{*}$ & $15.32(3.59)$ & $10.29(4.65)$ & $0.01^{* *}$ \\
\hline Ql estimated & 96.71 (11.92) & $100.26(8.93)$ & .124 & $104.42(9.36)$ & $92.95(8.7)$ & $0.01 * *$ \\
\hline HVLT immediate & $20.43(4.28)$ & $23.82(0.95)$ & .704 & 22.05 (3.49) & $19.43(4.15)$ & $0.04^{* *}$ \\
\hline HVLT late & $6.24(2.39)$ & $7.16(2.27)$ & .185 & $7.32(2.5)$ & $6.1(2.1)$ & 0.1 \\
\hline HVLT recognition & $9.43(1.47)$ & $9.84(1.74)$ & .334 & $10.16(1.26)$ & $9.14(1.74)$ & $0.05^{*}$ \\
\hline BVMT immediate & $17.38(7.9)$ & $13.47(9.26)$ & .158 & $18.11(9.72)$ & $13.19(7.07)$ & 0.13 \\
\hline BVMT late & $7.24(3.55)$ & $5.74(3.46)$ & .157 & $7.37(3.64)$ & $5.76(3.36)$ & 0.17 \\
\hline BVMT recognition & $5.67(1.71)$ & $4.95(0.85)$ & $.059^{*}$ & $5.58(1.77)$ & $5.1(0.94)$ & 0.49 \\
\hline Digits & $10.86(2.74)$ & $10.37(2.61)$ & .584 & $11.79(2.32)$ & $9.57(2.54)$ & $0.01^{* *}$ \\
\hline TMT A & $68.14(36.22)$ & $72.16(38.64)$ & .766 & $56.89(26.11)$ & $81.95(41.68)$ & $0.03^{* *}$ \\
\hline TMT B & 170.52 (89.58) & 157.74 (69.94) & .635 & $123.89(44.6)$ & 201.14 (87.99) & $0.01^{* *}$ \\
\hline FAS & $25.48(8)$ & 27.37 (8.58) & .472 & $29.53(6.98)$ & $23.52(8.38)$ & $0.02^{* *}$ \\
\hline Category & 12.48 (3.79) & $12.53(3.52)$ & .989 & $13.53(3.64)$ & $11.57(3.41)$ & $0.09^{*}$ \\
\hline Symbol digit & $28.86(12.63)$ & $31.42(11.81)$ & .464 & $35.42(10.57)$ & $25.24(11.67)$ & $0.01^{* *}$ \\
\hline Stroop C & $43.91(12.91)$ & $40.63(16.73)$ & .356 & $38.26(7.84)$ & $45.33(18.48)$ & 0.25 \\
\hline Clock & $7.9(2.07)$ & $7.05(3.06)$ & .600 & $7.95(2.66)$ & $7.1(2.53)$ & 0.24 \\
\hline Grooved A & $111.9(50.3)$ & $125.53(65.8)$ & .448 & 101.42 (48.79) & 133.71 (62.09) & $0.06^{*}$ \\
\hline Grooved B & 130.29 (52.69) & $128(54.97)$ & .839 & $118.79(50.58)$ & $138.62(54.77)$ & 0.15 \\
\hline
\end{tabular}

*Tendency to statistical significance; ${ }^{* *} \mathrm{p} \leq 0.05$ statistical significance. 
Table 3. Comparison of averages and significance statistics in groups of MELD and considering the Groups 1 and 2 to 40 patients of the hepatic transplant list of the HC-FMUSP.

\begin{tabular}{|c|c|c|c|c|c|c|}
\hline & \multicolumn{3}{|c|}{ Group 1 (education > 8) } & \multicolumn{3}{|c|}{ Group 2 (education $\leq 8$ ) } \\
\hline & $\begin{array}{c}\text { MELD } \geq 15 \\
\mathrm{n}=9 \text { mean }(\mathrm{SD})\end{array}$ & $\begin{array}{c}\text { MELD }<15 \\
\mathrm{n}=10 \text { mean }(\mathrm{SD})\end{array}$ & $\begin{array}{l}\text { Value } \\
\text { of } p\end{array}$ & $\begin{array}{c}\text { MELD } \geq 15 \\
\mathrm{n}=9 \text { mean }(S D)\end{array}$ & $\begin{array}{c}\text { MELD }<15 \\
\mathrm{n}=6 \text { mean }(S D)\end{array}$ & $\begin{array}{l}\text { Value } \\
\text { of } p\end{array}$ \\
\hline Schooling (years) & $11.78(2.22)$ & $11.1(1.91)$ & 0.38 & $52.58(8.11)$ & $54.56(6.71)$ & 0.65 \\
\hline MELD & $18.56(2.7)$ & $11.1(1.85)$ & $0.01^{* *}$ & $4.58(1.93)$ & $5.33(2)$ & $0.01 * *$ \\
\hline BECK & $11.56(7.63)$ & $10.2(6.3)$ & 0.97 & $11.5(6.23)$ & $13.78(8.66)$ & 0.64 \\
\hline SCID & $0.67(2)$ & 0 & 0.29 & $0.5(1.73)$ & $1.33(2.65)$ & 0.38 \\
\hline Vocabulary & $42(8.06)$ & $33.3(8.04)$ & $0.03^{* *}$ & $28.08(7.03)$ & $30.44(10.13)$ & 0.5 \\
\hline Matrix reasoning & $16.44(4.25)$ & $14.3(2.71)$ & $0.07^{*}$ & $7.58(2.61)$ & $13.89(4.37)$ & $0.01^{* *}$ \\
\hline Ql estimated & $107.56(10.2)$ & $101.6(8)$ & 0.46 & $88.58(3.8)$ & $98.78(10.13)$ & $0.01 * *$ \\
\hline HVLT immediate & $22.56(3.94)$ & $21.6(3.17)$ & 0.68 & $18.83(3.95)$ & $20.22(4.52)$ & 0.57 \\
\hline HVLT late & $7.33(2.55)$ & $7.3(2.58)$ & 0.84 & $5.42(1.98)$ & $7(2)$ & $0.09 *$ \\
\hline HVLT recognition & $10.33(1)$ & $10(1.49)$ & 0.73 & $8.75(1.42)$ & $9.67(2.06)$ & 0.23 \\
\hline BVMT immediate & $22.22(6.82)$ & $14.4(10.75)$ & 0.12 & $13.75(6.78)$ & $12.44(7.78)$ & 0.7 \\
\hline BVMT late & $9(3.2)$ & $5.9(3.51)$ & $0.05^{* *}$ & $5.92(3.32)$ & $5.56(3.61)$ & 0.64 \\
\hline BVMT recognition & $6(2.45)$ & $5.2(0.79)$ & 0.43 & $5.42(0.9)$ & $4.67(0.87)$ & $0.05^{* *}$ \\
\hline Digits & $12.89(2.71)$ & $10.8(1.4)$ & $0.05^{* *}$ & $9.33(1.56)$ & $9.89(3.55)$ & 0.61 \\
\hline TMT A & $51.67(15.68)$ & $61.6(33.06)$ & 0.65 & 80.5 (42.63) & 83.89 (42.85) & 0.92 \\
\hline TMT B & $103.33(26.37)$ & $142.4(50.56)$ & $0.09 *$ & 220.92 (87.29) & $174.78(86.66)$ & 0.14 \\
\hline FAS & $29.78(8.35)$ & $29.3(5.95)$ & 0.9 & $22.25(6.25)$ & $25.22(10.77)$ & 0.59 \\
\hline Category & 14.22 (3.63) & $12.9(3.73)$ & 0.41 & $11.17(3.49)$ & $12.11(3.44)$ & 0.69 \\
\hline Symbol digit & $36.89(10.78)$ & $34.1(10.79)$ & 0.54 & $22.83(10.65)$ & $28.44(12.81)$ & 0.36 \\
\hline Stroop C & $38.78(9.27)$ & $37.8(6.8)$ & 0.84 & 46.5 (14.59) & 43.78 (23.59) & 0.34 \\
\hline Clock & $8.22(2.22)$ & 7.7 (3.09) & 0.74 & $7.67(2.02)$ & 6.33 (3.04) & 0.37 \\
\hline Grooved A & $89.56(31.5)$ & $112.1(60.1)$ & 0.51 & $128.67(56.24)$ & 140.44 (72.12) & 0.57 \\
\hline Grooved B & $120.22(55.93)$ & $117.5(48.31)$ & 0.97 & $137.83(51.26)$ & 139.67 (62.31) & 0.97 \\
\hline
\end{tabular}

*Tendency to statistical significance; ${ }^{* *} \mathrm{p} \leq 0.05$ statistical significance.

results showed no significant differences. Nevertheless, there was a trend towards significant difference on the Matrix Reasoning and visual-spatial episodic memory test BVMT (recognition) for the group with MELD $\geq 15$.

In order to investigate possible educational level interference on the results, the patients were divided into two groups according to the years of education (Table 2). Group 1, included patients with more than 8 years of education and Group 2, patients with 8 years or less. The results showed a significant difference between the two groups on the vocabulary, matrix reasoning, estimated IQ, HVLT (immediate recall), digits, TMT A and B, FAS and symbol digit tests and a trend towards significant difference on the category fluency, Grooved A and HVLT (recognition). Group 1 had a better performance on those measures. On the depression scales, Group 2 had greater frequency of depressive symptoms.

Subsequently, Group 1 and 2 were compared on the same variables considering the MELD scores ( $\geq 15$ and $<15)^{22}$. For Group 1 (22.5\% with MELD $\geq 15$ and $25 \%$ with MELD <15), patients with MELD $\geq 15$ had a significant better performance on the vocabulary, BVMT (delayed recall) and digits, and tendency towards statistical signif- icance on matrix reasoning, TMT B and more frequency of depressive symptoms although not statistically significant (Table 3).

For Group 2 (22.5\% with MELD $\geq 15$ and 15\% with MELD <15), patients with MELD < 15 obtained significant better results on the matrix reasoning and estimated IQ, and a tendency towards statistical significance on the HVLT (delayed recall) and more depressive symptoms although not statistically significant (Table 3).

Finally, subjects with or without history of alcohol abuse were compared on the same variables. The results showed no significant differences between these two groups of subjects.

\section{DISCUSSION}

In this study, the cognitive performance and mood were investigated in a sample of patients from a waiting list for liver transplantation. These results were analyzed taking into consideration the MELD and the presence or not of HE. Previous studies have demonstrated the presence of psychomotor speed, attention and visual-perception deficits ${ }^{5,22,23}$ in cases with minimal HE. In the present sample, there was a trend towards significance on the ma- 
trix reasoning subtest (WAIS-III) ${ }^{15}$, which measures nonverbal reasoning and also visual-perceptual skills.

In the investigation of mood, there was a higher frequency of depressive symptoms in patients from the group with MELD scores $<15$, probably because of their recent inclusion in the list of transplant. A study carried out in Ribeirão Preto ${ }^{7}$ showed that there is an inversely correlation between associated hepatic problems and period of time spent on the waiting list for liver transplantation. This was also related to an improvement in psychological state due to interruption in the use of alcohol and clinic stabilization ${ }^{7}$.

When years of education were taken into account, the better performance of patients with higher education corroborates previous studies showing similar results. These findings also suggest the possibility of the contribution of the cognitive reserve ${ }^{24,25}$. Patients with higher educational level have greater potential cognitive reserve in face of neuropsychological injuries ${ }^{26}$, including those resulting from hepatic diseases. Thus, it is speculated that patients with low education are more vulnerable to these effects associated with the $\mathrm{EH}^{27}$.

The results from the later analyses showed significant statistical differences between the groups with MELD $\geq 15$ and $<15$ in verbal reasoning, visual-spatial episodic memory (delayed recall), short term memory and a tendency towards significant differences in non-verbal reasoning and alternating attention with better performance for patients with more than 8 years of education. The patients with $\leq 8$ years of education showed better results in non-verbal reasoning and visual-spatial episodic memory (recognition), and tendency towards significant difference in verbal episodic memory (delayed recall, see Table 3 ). It should be noted that despite the low educational level, these patients had MELD $<15$, which could explain their better performance. These findings support another study which showed difficulties in memory, attention and mental flexibility correlated with the deterioration of the hepatic disease measured by the MELD ${ }^{28}$. Difficulties in short term memory, verbal long term memory and learning ability can be a result of attentional deficits, as supported by other studies ${ }^{5}$.

In the current study, the main deficits were associated to visual-spatial episodic memory and recognition, revealing that visual-perceptual and visual-spatial problems, usually seen in $\mathrm{HE}^{4}$, may be an important factor contributing to these deficits.

Although chronic alcoholic abuse is considered as a predictor of cognitive impairments ${ }^{29}$, the lack of statistical significance in the current study can be explained by the alcoholic abstinence over five years among the subjects.

One limitation of the current study was the small sample size. Nevertheless, these findings corroborate previous studies and emphasize the need to investigate the cognitive functioning and mood of these patients in a systematic way in order to plan and decide specific interventions.

\section{REFERENCES}

1. Bianchi G, Marchesini G, Nicolino F, et al. Psychological status and depression in patients with liver cirrhosis. Dig Liver Dis 2005;24:564-565.

2. Forton DM, Thomas HC, Murphy CA, et al. Hepatitis C and Cognitive Impairment in a Cohort of Patients With Mild Liver Disease. Hepatology 2002;35:433-439.

3. Senzolo M, Amodio P, D'Aloiso MC, et al. Neuropsychological and neurophysiological evaluation in cirrhotic patients with minimal hepatic encephalopathy undergoing liver transplantation. Transplant Proc 2007;37:1104-1107.

4. Weissenborn K, Heidenreich S, Ennen J, Reickert N, Hecker H. Attention deficits in minimal hepatic encephalopathy. Metab Brain Dis 2001;16:13-19.

5. Weissenborn K, Heidenreich S, Giewekemeyer K, Hecker H. Memory function in early hepatic encephalopathy. J Hepatol 2003;39:320-325.

6. Orrú MG, Pariante MC. Depression and liver disease. Dig Liver Dis 2005;37:564-565.

7. Martins PD, Sankarankutty AK, Silva OC, Gorayeb R. Psychological distress in patients listed for liver transplantation. Acta Cir Bras 2001;21(Suppl 1): S40-S43.

8. Pugh RNH, Murray-Lyon IM, Dawson JL, Pietroni MC, Willians R. Transection of the oesophagus for bleeding oesophageal varices. Br J Surg 1973;60:646-649.

9. Rocca P, Cocuzza E, Rasetti R, Rocca G, Zanalda E, Bogetto F. Predictors of psychiatric disorders in liver transplantation candidates: logistic regression models. Liver Transpl 2003;9:721-726.

10. Gayotto LCC, Álvares VAF. Doenças do fígado e vias biliares. São Paulo: Editora Atheneu, 2001

11. Choi PC, Kim HJ, Choi WH, Park D, et al. Model for end-stage liver disease, model for end-stage liver disease-sodium and Child-Turcotte-Pugh scores over time for the prediction of complications of liver cirrhosis. Liver Int 2008;9:221-226.

12. Critério de MELD para transplante hepático. Available at www.hepcentro. com.br/portaria1160.htm. Accessed (07/24/2008).

13. Cunha JA. Manual da versão em Português das Escalas Beck. São Paulo: Casa do Psicólogo, 2001.

14. Michael B, Spitzer RTL, Gibbon M, Williams J. Structured clinical interview for DSM-IV Axis I disorders - Patient edition ( $2^{\text {nd }}$ Ed). New York: Biometrics research department, 1998.

15. Nascimento E. WAIS-III: Escala de inteligência Wechsler para adultos: Manual David Wechsler; Adaptação e padronização de uma amostra brasileira (1 a Ed). Tradução Maria Cecília de Vilhena Moraes Silva. São Paulo: Casa do Psicólogo, 2004.

16. Ringe WK, Saine KC, Laura HL, Linda SH, Munro CC. Dyadic short forms os the Wechsler adult intelligence scale-III. Assessmen 2002;3:254-260.

17. Brandt J, Benedict RHB. Hopkins verbal learning test- revised. Odessa: Psychological Assessment Resourse, 2001.

18. Benedict RHB. Brief visualspatial memory test- revised. Odessa: Psychological Assessment Resourse, 1997.

19. Strauss E, Sherman EMS, Spreen O. A compendium of neuropsychological tests: administration, norms, and commentary $\left(2^{\text {nd }} E d\right)$. New York: Oxford University Press, 1998

20. Smith A. Symbol digit modalities test - Manual ( $9^{\text {th }}$ Ed). Los Angeles: University of Michigan, 2002.

21. Strauss E, Sherman EMS, Spreen O. A compendium of neuropsychological test: administration, norms, and Commentary ( $3^{\text {th }}$ Ed). New York: Oxford University Press, 2006

22. Robert MM. When is a patient too well and when is a patient too sick for a liver transplant. Liver Transpl 2004;10(Suppl 2):S69-S73.

23. Weissenborn K, Ennen JC, Schomerus, H, Ruèckert N, Hecke H. Neuropsychological characterization of hepatic encephalopathy. J Hepatol 2001;34:768-773.

24. Bleecker ML, Ford DP, Celio MA, Vaughan CG, Lindgren KN. Impact of cognitive reserve on the relationship of lead exposure and neurobehavioral performance. Neurology 2007;69:470-476.

25. Staff RT, Murray AD, Deary IJ, Whalley LJ. What provides cerebral reserve? Brain 2004;127:1191-1199.

26. Ngandu T, Strauss EV, Helkala E-L, et al. Education and dementia. What lies behind the association? Neurology 2007;69:1442-1450.

27. Bieliauskas LA, Back-Madruga C, Lindsay KL, et al. Cognitive reserve and neuropsychological functioning in patients infected with hepatitis C. J Int Neuropsychol Soc 2007;13:687-692.

28. Meyer T, Eshelman A, Abouljoud M. Neuropsychological changes in a large sample of liver transplant candidates. Transplant Proc 2006;38:3559-3560.

29. Ruitenberg A, Swieten JC, Witteman JCM, et al. Alcohol consumption and risk of dementia: the Rotterdam Study. Lancet 2002;359:281-286. 